\title{
The importance of willow to the Chinese Grouse: evidence from analysis on their breeding territories at Lianhuashan, China
}

Jin-Ming Zhao ${ }^{1,2}$, Yun Fang ${ }^{1}$, Yu-Hai Ma ${ }^{3}$ and Yue-Hua Sun ${ }^{1 *}$ (0)

\begin{abstract}
Background: The habitat features of breeding territory have important adaptive significance for the survival and reproduction of territory holders. The Chinese Grouse (Tetrastes sewerzowi) is a rare and endemic species with relatively small distribution range and decreasing population trend. It is important to elucidate breeding territory habitat requirements of the Chinese Grouse for habitat management and conservation actions.

Methods: Using radio-telemetry and field observations, we determined the core areas of 65 breeding territories of males. Two to three samples were selected in each core breeding territory as used sites and compared with nearby sites with no grouse occurrence using logistic regression.
\end{abstract}

Results: Our model showed a high accuracy in prediction of core breeding territory used by males, which preferred stands with more small deciduous trees $(0.5 \mathrm{~m} \leq$ height $<5 \mathrm{~m}$ ), more small willow trees (Salix spp.,

$0.5 \mathrm{~m} \leq$ height $<5 \mathrm{~m}$ ), greater willow cover, and greater herb cover. The number of small willow trees had the greatest influence on males' core breeding territory selection. Dense shrubs were also chosen compared with unused sites. Tall conifer trees was an important determinant in the distribution of Chinese Grouse at the landscape scale, and was relatively important in the univariate model, but not included in our final multivariable model.

Conclusions: Male Chinese Grouse established territories at sites with abundant food resources. At the landscape scale, the Chinese Grouse occurred in alpine conifer forest. At the territory scale, small willow trees had the most important effect on males' core breeding territory selection. We suggest that the forest gaps in dense conifer forest are important for improving the occurrence of willows and facilitating breeding territory establishment for the Chinese Grouse.

Keywords: Salix spp., Chinese Grouse, Territory, Core area, Conifer forest, Logistic regression

\section{Background}

The distribution of animals depends on interactions between the distributions of required resources and their ability to acquire these resources (Morris 2003; Jones and Siefferman 2014; Akresh et al. 2015). In monogamous bird species, breeding territory habitat selection determines their distributions in the breeding season (Boves et al. 2013; Reiley et al. 2013). Breeding territory habitat

\footnotetext{
*Correspondence: sunyh@ioz.ac.cn

${ }^{1}$ Key Laboratory of Animal Ecology and Conservation Biology, Institute of Zoology, Chinese Academy of Sciences, Beijing 100101, China Full list of author information is available at the end of the article
}

features have an important adaptive significance for the survival and fecundity of their owners, as they not only provide food and shelter, but also influence mate acquisition and offspring survival (Holt et al. 2011; Chalfoun and Schmidt 2012; Rahman et al. 2012). Thus, breeding territory habitat selection affects population sustainability and dynamics (Nystrand et al. 2010; Hollander et al. 2011). Elucidating and understanding the breeding habitat features of rare avian species is pivotal for their conservation.

In a heterogeneous breeding territory, the owner makes differential use of the parts of the territory according to its life purposes (e.g. feeding, nesting, Barg et al. 
2006). Core areas of a territory are sites that are used most frequently, and are potentially important to their owners (Barg et al. 2006). These areas are thought to be most important for breeding territory selection and draw a great deal of attentions from researchers, because these are where individuals are most frequently found (Liu 1987; Barg et al. 2004). As core areas only occupy a small part in a breeding territory, and acquires most intensive use, they have great conservation value and are important for the habitat management of focal species, especially rare species.

With a decreasing population trend and distribution confined to alpine conifer forests along the east edge of the Qinghai-Tibetan Plateau (elevation range 2400$4300 \mathrm{~m}$ ), the endemic Chinese Grouse (Tetrastes sewerzowi) is considered as "near threatened" by IUCN (2013 version) and is listed as a category I national protected animal by the Chinese government (Zheng and Wang 1998; Sun 2004). As a monogamous bird (Bergmann et al. 1996; Sun and Fang 1997), male Chinese Grouse hold territories and females choose males to pair with and they nest in the males' territories (Sun and Fang 1997; Sun et al. 2003). Territory quality is thought to play an important role in the fitness of males (Sun and Fang 2010), and thus might have important effects on its population sustainability and dynamics. However, information regarding the features of male breeding territories is lacking, although this knowledge is valuable for population recovery.

In this study, we compared habitat features of core areas in males' territories with areas outside of males' territories. We predicted that willow shrubs would an important factor as willow buds constitute the most important food resource during pairing and egg laying periods (Wang et al. 2010). In addition, predation risk also influences the birds' habitat selection, we thus expected that core areas of territories would have good concealment, i.e., greater shrub cover. Finally, as the distributions of Chinese Grouse corresponds with alpine conifer forest (Sun 2000), we expected the occurrence and density of conifer trees would also play an important role in territory selection.

\section{Methods}

\section{Study area}

The study was conducted at Lianhuashan Nature Reserve $\left(34^{\circ} 40^{\prime} 67^{\prime \prime} \mathrm{N}, 103^{\circ} 30^{\prime} 84^{\prime \prime} \mathrm{E}\right)$, Gansu, China, 2009-2012. With an area of 11,691 ha, this reserve was set up in 1983 to protect various natural forest ecosystems. Vegetation types comprised original conifer forests (Abies fargesii, Picea purpurea, P. crassifolia), deciduous forests (Betula platyphylla, B. albosinensis,
B. utilis, Populus davidiana), conifer deciduous mixed forests, shrubs (Salix oritrepha, S. caprea, S. cupularis, Hippophae rhamnoides, Rosa hugonis, Berberis kansuensis, Rhododendron anthopogonoides, R. rufum, R. przewalskii, Sorbus koehneana), alpine meadows, farmlands, villages, rocks and rivers (Klaus et al. 1996). Vegetation types change dramatically along altitudes from 2000 to $3500 \mathrm{~m}$. We conducted our research in an area of about $4 \mathrm{~km}^{2}$ in the western part of the reserve, where original conifer forests are distributed and has the highest population density in the reserve. In the remaining conifer forests, trees had been cut selectively and roads were constructed to facilitate timber transport before the reserve was established. In such areas, deciduous trees, such as willows and birches, were interspersed in the conifer forests, which constituted favorite spots for the Chinese Grouse. For detailed description of climate and vegetation, please see Sun et al. (2003).

\section{Territory delineation}

Male Chinese Grouse core breeding territories were confirmed by two methods, from 48 radio-tracked males and from observations of unmarked males from the last 10 days of April to first 20 days of May. This was before incubation started and when males exhibited most extensive territory behaviors during 2009-2012. Males were caught using ground nets or walk in traps in April, and released after being measured and fitted with necklace radio-transmitters (Holihil; Model RI-2B). Transmitters weighed about 9 g (less than $3 \%$ of the bird's body weight) and had an expected battery life of 12 months. We radio tracked males between 6:30 to $10: 00$ am and 15:00 to $17: 30 \mathrm{pm}, 1-2$ times per day using a 2-element Yagi antenna (Biotrack Ltd., Dorset, UK). Radio-tracked males' positions were acquired using the triangulation method (White and Garrott 1990). Territories were described using the Geospatial Modeling Environment (Beyer 2012). We used the 50\% fixed kernel method to determine the core areas of a territory. During radio tracking, we spot mapped males without transmitters. We validated an untagged male' territory when we observed a male at the same site at least 5 times during 20 April to 20 May in each year. We used this method because males were sedentary in their territories and easy to observe with conspicuous territory behaviors in this period. All capture, radio-tagging, and tracking procedures used in the present study had received prior approval and were supervised by the Animal Care and Use Committee of the Institute of Zoology, the Chinese Academy of Sciences (Project No. 2008/73) 


\section{Habitat measurement}

We employed a used-unused design to compare variables in core areas and outside males' breeding territories (Jones 2001). Used sites were selected randomly in a male's core breeding territory areas; $2-3$ samples were selected in each territory (Fig. 1). The unused sites were determined 100-200 $\mathrm{m}$ from the used sites that were not being used by males during radio tracking and other field works. At both used and unused sites, we measured 20 variables on a scale of $20 \mathrm{~m} \times 20 \mathrm{~m}$. The set of variables consisted of topographic, structural, and compositional variables. Variables were assigned to the tree (height $\geq 5 \mathrm{~m})$, shrub $(0.5 \mathrm{~m} \leq$ height $<5 \mathrm{~m})$, and ground (height $<0.5 \mathrm{~m}$ ) layers to characterize the structure of the stands (Table 1). We also included important food plants (e.g. willows) of the Chinese Grouse (Wang et al. 2010). Canopy cover, willow cover, and shrub cover were measured using the line intercept method along two 20-m lines in two main directions perpendicularly crossing the center of the site (Canfield 1941). Numbers of coniferous trees (height $\geq 5 \mathrm{~m}$ ), small coniferous trees $(0.5 \mathrm{~m} \leq$ height $<5 \mathrm{~m})$, deciduous trees (height $\geq 5 \mathrm{~m}$ ), small deciduous trees $(0.5 \mathrm{~m} \leq$ height $<5 \mathrm{~m})$, willow trees (height $\geq 5 \mathrm{~m})$, small willow trees $(0.5 \mathrm{~m} \leq$ height $<5 \mathrm{~m})$, rowan trees (height $\geq 0.5 \mathrm{~m}$ ), and dead wood (length $\geq 0.5 \mathrm{~m}$, diameter $\geq 8 \mathrm{~cm}$ ) were counted within $0.5 \mathrm{~m}$ from and on both sides of the two 20 -m perpendicular lines. From this, the density of these variables were calculated in per hectare. Grass cover, herb cover, moss cover, and fern cover were estimated using a $20 \mathrm{~cm} \times 50 \mathrm{~cm}$ PVC frame (Daubenmire 1959).

\section{Statistical analyses}

We employed whether the site was a used core breeding territory or an unused area as a response variable and habitat features as predictor variables to build models using logistic regression (Janzen and

Table 1 Variables that were used to characterize core breeding territory habitat sites (20 $\mathrm{m} \times 20 \mathrm{~m}$ ) and unused sites of male Chinese Grouse, at Lianhuashan, Gansu, China, 2009-2012

\begin{tabular}{|c|c|}
\hline Variable & Definition \\
\hline Slope aspect & Slope aspect in ${ }^{\circ}$ \\
\hline Slope gradient & Slope gradient in ${ }^{\circ}$ \\
\hline Distance to edge & Length between forest and gaps/clearance in m \\
\hline Distance to water & Length between forest and creek/water hole \\
\hline Tall deciduous trees & Number of deciduous trees $(\geq 5 \mathrm{~m}$ ) per ha \\
\hline Small deciduous trees & Number of deciduous trees and bushes (height: $\geq 0.5 \mathrm{~m},<5 \mathrm{~m}$ ) per ha \\
\hline Tall coniferous trees & Number of coniferous trees ( $\geq 5 \mathrm{~m}$ ) per ha \\
\hline Small coniferous trees & Number of coniferous trees (height: $\geq 0.5 \mathrm{~m},<5 \mathrm{~m}$ ) per ha \\
\hline Tall willow trees & Number of willow trees $(\geq 5 \mathrm{~m})$ per ha \\
\hline Small willow trees & Number of willow trees (height: $\geq 0.5 \mathrm{~m},<5 \mathrm{~m}$ ) per ha \\
\hline Willow cover & Area covered by willow trees $\geq 0.5 \mathrm{~m}$, estimated in $10 \%$ steps \\
\hline Rowan trees & Number of rowan trees $(\geq 0.5 \mathrm{~m})$ per ha \\
\hline Canopy cover & Area covered by crowns, estimated in $10 \%$ steps \\
\hline Shrub cover & Area covered by shrub layer $(\geq 0.5 \mathrm{~m},<5 \mathrm{~m})$ in $10 \%$ steps \\
\hline Grass cover & Area covered by grass, estimated in $10 \%$ steps \\
\hline Herbaceous cover & Area covered by herbaceous, estimated in $10 \%$ steps \\
\hline Fern cover & Area covered by fern, estimated in $10 \%$ steps \\
\hline Moss cover & Area covered by moss, estimated in $10 \%$ steps \\
\hline \multirow[t]{5}{*}{ Stand structure } & Stand structure in four categories \\
\hline & $1=$ one layered \\
\hline & $2=$ two layered \\
\hline & $3=$ three layered \\
\hline & $4=$ multi-layered \\
\hline \multirow[t]{5}{*}{ Stem structure } & Stem distribution in four categories \\
\hline & $1=$ crowed, defined as canopy closure $(\geq 0.8)$ \\
\hline & $2=$ normal, defied as canopy closure $(\geq 0.3,<0.8)$ \\
\hline & $3=$ spare, defined as canopy closure $(\geq 0.1,<0.3)$ \\
\hline & $4=$ grouped, defined as canopy closure $(\geq 0,<0.1)$ \\
\hline
\end{tabular}


Stern 1998; Keating and Cherry 2004). We reduced the independent variable set in three steps, because a large variable set risk overfitting the model and consequently lose generality and interpretability (Schäublin and Bollmann 2011; Ludwig and Klaus 2016). In a first step, we assessed bivariate correlation, because multicollinearity could cause problems in logistic regression (Hosmer and Lemeshow 2000). In cases with correlations $r \geq 0.7$ (Spearman/Pearson rank correlation), the variable with least explanatory potential was excluded from further analysis (Schäublin and Bollmann 2011). In a second step, we analyzed univariate logistic models for each independent variable and significant variables $(p<0.05)$ were retained for further analysis. In a third step, we constructed a full model containing all significant independent variables left in the second step, and then reduced them in a stepwise manner using logistic regression based on Akaike's information criterion (Akaike 1974; Burnham and Anderson 2002). We assessed model fit by calculating AUC, the area under the receiver operating characteristic curve (ROC), which can vary between 0.5 (worst fit) and 1 (best fit) (Hosmer and Lemeshow 2000; Dussault et al. 2005). Parameter estimates with standard errors and odds ratio were also calculated. Finally, we calculated means and standard errors of all variables that contributed significantly to a model of territory occupancy probability.

All statistics were performed on SAS 9.1 (SAS institute, Cary, NC), with all results presented with mean \pm standard error.

\section{Results}

Totally, we analyzed 139 core territory plots (107 from 48 radio-tracked males and 32 from 19 spot-mapped males) and 139 unused plots. Bivariate correlation analyses indicated significantly multicollinearity occurred between variables stand shrub cover and small deciduous trees $(r=0.842)$, shrub cover and small willow trees $(r=0.712)$, shrub cover and canopy cover $(r=-0.845)$, stand structure and small deciduous trees $(r=0.753)$, stem structure and canopy cover $(r=-0.892)$, stem structure and shrub cover $(r=0.810)$. We removed shrub cover, stand structure, and stem structure from further analysis. In the remaining 17 variables, 12 variables were significant in the univariate analyses and were thus subjected to multivariate analysis (Table 2). The number of small deciduous trees, the number of small willow trees, the total area of willow cover each yielded high explanatory power, with $R^{2}>0.6$. The variables "herb cover" and "tall coniferous trees" explained a relatively high proportion of the model's variance (both $R^{2}>0.4$ ).

The best multivariate model obtained from stepwise reduction and selection by AIC retained four of the 12 predictor variables entered: small willow trees, small deciduous trees, willow cover, and herb cover (Table 2), all of which positively influenced core territory use (Tables 2 , 3 ). The number of small willow trees had the strongest effect, with a standardized regression coefficient estimate value of 2.126 (Table 3). On average $3900.0 \pm 90.9$ small deciduous trees per hectare were found at used sites, compared to only $1143.9 \pm 67.1$ small deciduous trees per hectare at the unused sites (Fig. 2a). The respective

Table 2 Results of core territory characteristics of Chinese Grouse using logistic regression, with their regression estimate coefficients $\beta, p$ values and $R^{2}$ values presented

\begin{tabular}{|c|c|c|c|c|c|c|}
\hline \multirow[t]{2}{*}{ Variable } & \multicolumn{3}{|c|}{ Univariable models } & \multicolumn{3}{|c|}{ Multivariable model } \\
\hline & $\beta$ & $p$ & $R^{2}$ & $\beta$ & SE & $p$ \\
\hline Intercept & & & & -9.879 & 2.220 & $<0.001$ \\
\hline Small deciduous trees & 0.003 & $<0.001$ & 0.644 & 0.002 & 0.0006 & 0.0005 \\
\hline Small willow trees & 0.005 & $<0.001$ & 0.626 & 0.005 & 0.002 & 0.005 \\
\hline Willow cover & 39.032 & $<0.001$ & 0.621 & 24.631 & 6.944 & 0.009 \\
\hline Herb cover & 33.903 & $<0.001$ & 0.472 & 23.178 & 8.642 & 0.007 \\
\hline Slope aspect & 0.427 & 0.012 & 0.021 & & & \\
\hline Slope gradient & -0.061 & $<0.001$ & 0.066 & & & \\
\hline Dead wood & -0.0004 & 0.008 & 0.024 & & & \\
\hline Tall deciduous trees & 0.001 & $<0.001$ & 0.156 & & & \\
\hline Tall willow trees & 0.002 & $<0.001$ & 0.139 & & & \\
\hline Tall coniferous trees & -0.004 & $<0.001$ & 0.470 & & & \\
\hline Rowan trees & 0.0004 & $<0.001$ & 0.094 & & & \\
\hline Grass cover & 2.834 & $<0.001$ & 0.050 & & & \\
\hline
\end{tabular}


Table 3 Standardized coefficient regression estimation and odds ratio of variables in the most important model of core territory characteristics of Chinese Grouse

\begin{tabular}{llrrr}
\hline Variable & $\begin{array}{l}\text { Standardized } \\
\text { estimate }\end{array}$ & Odds ratio & 95\% Wald Cl & \\
\hline $\begin{array}{l}\text { Small deciduous } \\
\text { trees }\end{array}$ & 1.925 & 1.002 & 1.001 & 1.003 \\
$\begin{array}{l}\text { Small willow } \\
\text { trees }\end{array}$ & 2.126 & 1.005 & 1.001 & 1.008 \\
$\begin{array}{l}\text { Willow cover } \\
\text { Herb cover }\end{array}$ & 1.802 & $>999.999$ & $>999.999$ & $>999.999$ \\
\hline
\end{tabular}

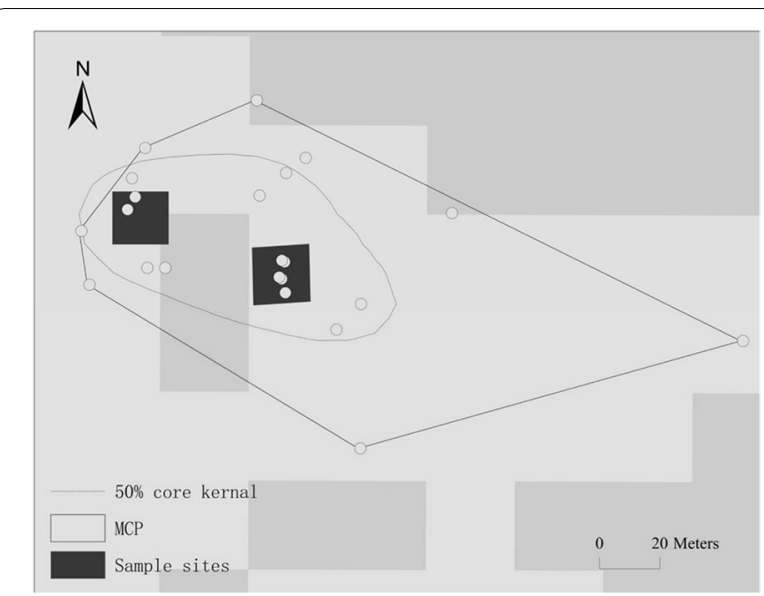

Fig. 1 The 50\% core breeding territory of a male Chinese Grouse and sample site location. The minimum convex polygon (MCP) is also illustrated. Dark gray: conifer forest; light gray: conifer and deciduous mixed forest

values for small willow trees were $2328.1 \pm 128.3$ per hectare at used sites and $64.7 \pm 16.0$ per hectare at unused sites (Fig. 2b). Willow cover was higher at used sites $(0.22 \pm 0.009)$ than at unused sites $(0.02 \pm 0.002$, Fig. $2 \mathrm{c})$. The value of herb cover was also higher at used sites $(0.12 \pm 0.006)$ than at unused sites $(0.01 \pm 0.003$, Fig. $2 \mathrm{~d})$. The final habitat model showed a max-rescaled $R^{2}$ of 0.961, and an AUC value of 0.998 (Fig. 3). Tall conifer trees were not included into the final model, in spite of its relative importance in the univariate analysis (Table 2).

\section{Discussion}

For the first time, we quantitatively described core breeding territory characteristics for the Chinese Grouse. Small willow trees, small deciduous trees, willow cover, and herb cover were the most important variables determined core breeding territory selection by the Chinese Grouse, and all four parameters had positive effects. Abundant small willow trees and big willow cover provided males the most important food resources in the pairing and prelaying periods, i.e., willow catkins, leaves, twigs, and buds, which constitute $98 \%$ of the wet contents of males' crops (Wang et al. 2010). In addition, territories with abundant small deciduous trees, and herb cover could supply the potential mates with more nutritious food, such as herb leaves and insects (Wang et al. 2010). Dense shrub layers could also decrease the detectability of predators as the grouse feed.

Previous studies have found that willows are important in determining the habitat selection of Chinese Grouse during spring (Ji et al. 2005), brood rearing (Zhao et al. 2015), and winter seasons (Yang et al. 2011). We found that willows were important in determining males' core territories during paring and egg-laying periods in this study. A much higher number of small willow trees (2328/ ha) was found in core breeding territory than winter habitat (570-1820/ha) (Yang et al. 2011). Males were more sedentary after occupying territories in spring; however, many males moved around in winter when most food resources in their territories were covered by deep snow. In such situations, the Chinese Grouse might lower their willow use and feed on other foods, such as the fruits of Sea Buckthorn (Hippophae rhamnoides) on sunny slopes (Sun et al. 2003). The number of willows in our results was also greater than in spring habitat selection, which was 1583 willows/ha (Ji et al. 2005). We can explain this, based on two aspects. One was that our used sites were at core areas of a male's territory, where a great deal of time was spent feeding on willows. The sample sites of Ji et al. (2005) were in the entire territories and less willows existed in noncore areas, such as nest sites at the peripheries of territories (Sun et al. 2007). Another explanation was that the areas examined by Ji et al. (2005) might have contained areas outside the territory, because females are not territoriality before pairing and nesting in a male's territory in spring (personal observation). Thus, we could summarize that the Chinese Grouse was willow dependent, and it relied on willows year round. During the pairing and egg-laying periods, willow selection by territorial males reached a peak, because of shortage of other food resources. Dependence on certain food sources in territory habitat selection has also been found in other Galliform species. Examples include Aspen (Populus spp.) for Ruffed Grouse (Tetrastes umbellus, Bump et al. 1947; Gullion 1977), Sagebrush (Artemisia spp.) for Greater Sage-grouse (Centrocercusu urophasianus, Wallestad and Schladweiler 1974; Leonard et al. 2000), Bilberry (Vaccinium spp.) for Capercaillie (Tetrao urogallus, Wegge et al. 2005), Alder (Alnus spp.) for Hazel Grouse (Tetrastes bonasia, Swenson 1993), and Daphniphyllum macropodum for Cabot's Tragopan (Tragopan caboti, Young et al. 1991).

At the landscape scale, the distribution of Chinese Grouse coincides with the distribution of alpine 

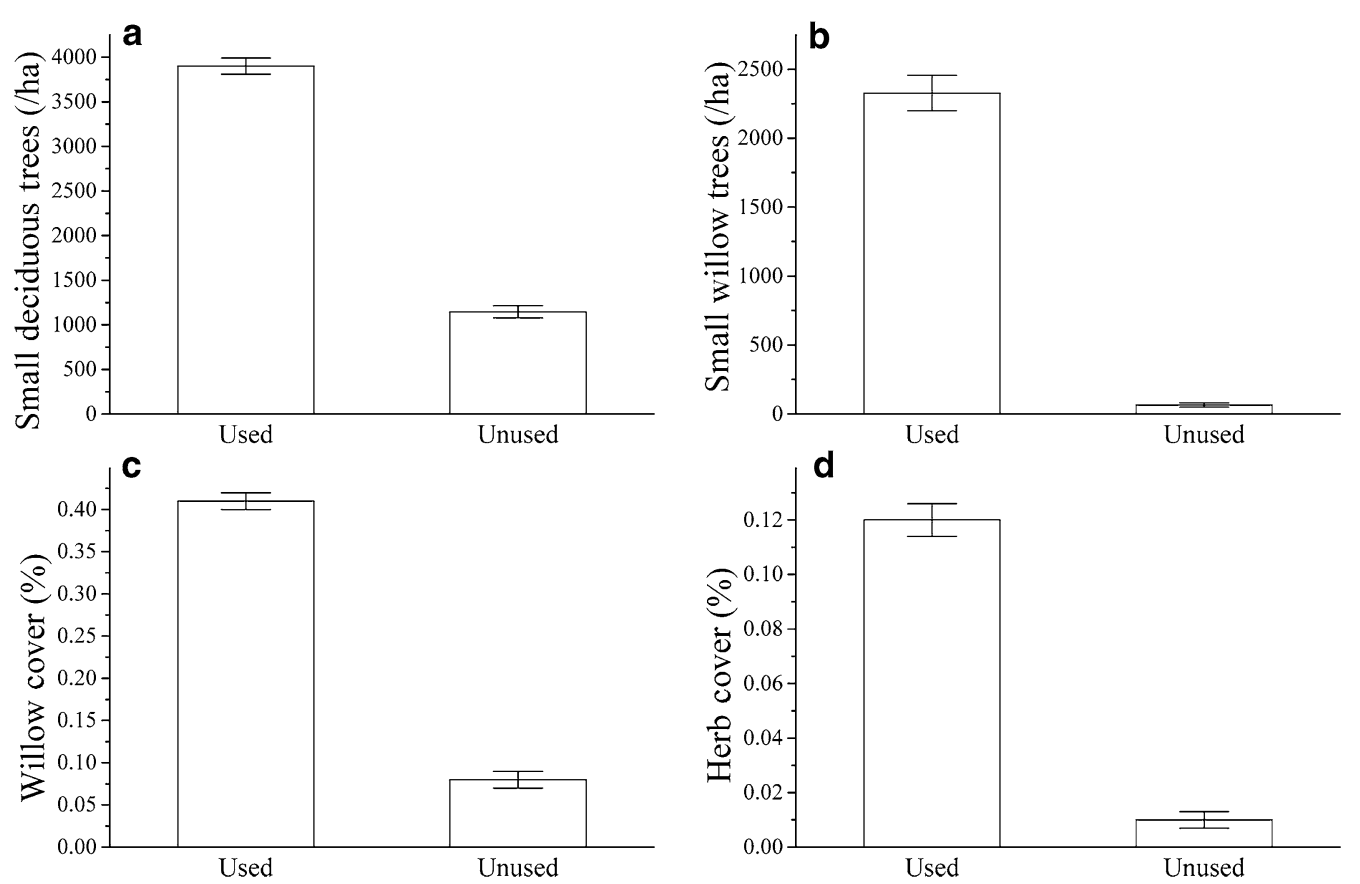

Fig. 2 Four most important variables determining Chinese Grouse core breeding territory habitat selection at Lianhuashan, Gansu, China. a Small deciduous trees per ha, b small willow trees per ha, c willow cover, $\mathbf{d}$ herb cover

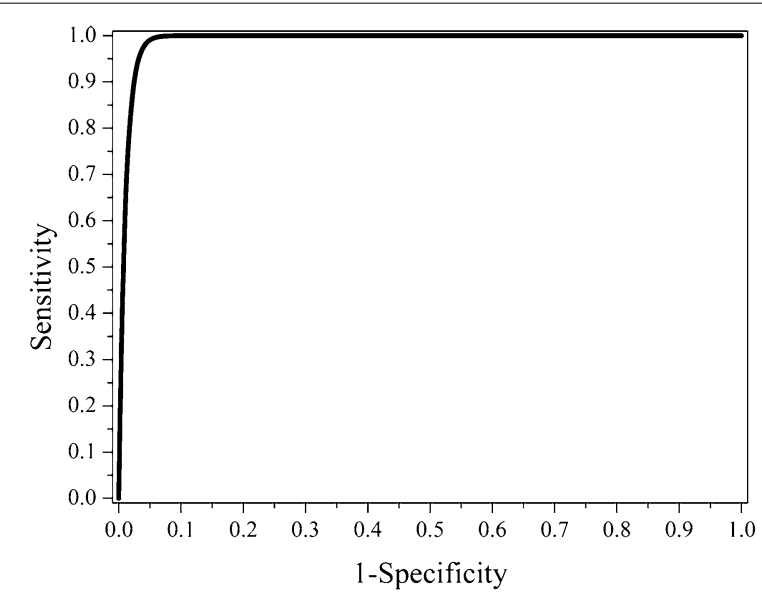

Fig. 3 The receiver operating characteristic curve from logistic regression illustrated a high accuracy in prediction of core breeding territory features of Chinese Grouse, with an area under curve (AUC) of 0.998

conifer forest (Sun 2000, 2004; Sun et al. 2006). At the territory scale, tall coniferous trees were relatively important in univariate models, but were not entered into our final model (see Table 2). This confirmed that habitat selection was scale dependent (Sergio et al. 2003; Mayor et al. 2009). In our study area, territories were all near conifer trees or in conifer forest gaps, where willows were abundant. We found that sites with more tall coniferous trees lacked shrubs and willows, which were important food sources and for concealment of Chinese Grouse. But, we could not rule out the importance of conifer trees in males' territory selection. Seeds of conifer trees were important food for their paired mates in the prelaying period, accounted for more than $40 \%$ of wet crop food content, the same percent as willows (Wang et al. 2010). Conifer trees also provide shelter for Chinese Grouse, such as roosting sites and refuge from predators (Swenson et al. 1995; Bergmann et al. 1996; Klaus et al. 1996), and a large portion of females nested at the bases of conifer trees in males' territories (Sun et al. 2007). Similar results have also been also found for the Giant Panda (Ailuropoda melanoleuca), which selects bamboo abundant sites at the microhabitat scale. However, older forests are as important as bamboo at the landscape scale (Zhang et al. 2011). In Chinese Grouse, larger conifer trees in core territories might also have contributed to breeding success and thus had a positive effect on the fitness of territory owners. We speculate that males should first guarantee an adequate amount of small willow trees, then as many tall coniferous trees as possible to attract females. Seeds of coniferous trees changed dramatically between years (Koenig and Knops 2000), so males might change the number of tall conifer trees in their core breeding territory annually in relation to conifer seed production. 
Herbs had not sprouted when territories were established in late April and early May. They constituted a small part of the food for paired females (Wang et al. 2010). However, it could attract more arthropod animals (Wegge et al. 2005), which could provide important nutrients for females before egg laying (Wang et al. 2010).

\section{Conclusions}

In conclusion, the most important features that determined male core breeding territory selection were food acquirements for males, and probably also for paired females. Males established territories at sites with abundant small willow trees. Dense small deciduous shrubs were also preferred, probably for concealment. Greater herb cover could provide additional foods for females. However, subalpine conifer forest was the most important determination of Chinese Grouse habitat selection at the landscape scale. In our study at the scale of territories, conifer trees were less important than willows. However, all willow trees were in gaps of conifer forests in our study area, so males must seek a balance between enough small willow trees and some conifer trees to occupy a territory. In hazel Grouse, natural rejuvenation in gaps after windfalls, insect calamities, or avalanches could enlarge habitat area in mountain forests (Schäublin and Bollmann 2011; Ludwig and Klaus 2016). For the Chinese Grouse, the naturel or anthropogenic enlargement of conifer forest gaps to facilitate growth of small willow trees would promote male Chinese Grouse to colonize, which in turn should promote fecundity and population growth.

\section{Authors' contributions}

JMZ and YHS conceived and designed the idea. YF, YHM and JMZ performed the field work. JMZ and YHS analyzed the data. JMZ and YHS wrote the paper. All authors read and approved the final manuscript.

\section{Author details}

${ }^{1}$ Key Laboratory of Animal Ecology and Conservation Biology, Institute of Zoology, Chinese Academy of Sciences, Beijing 100101, China. ${ }^{2}$ School of Resources and Environmental Engineering, Anhui University, Hefei 230601 China. ${ }^{3}$ Administration Bureau of Lianhuashan National Nature Reserve, Kangle 731516, Gansu, China.

\section{Acknowledgements}

We are grateful to Yahui Li, Yingqiang Lou, Mei Shi and Yang Hong for assistance in the field. We appreciate the support of the Lianhuashan Nature Reserve Authority. We are grateful to Prof. Jon E. Swenson for his help with English.

\section{Competing interests}

The authors declare that they have no competing interests.

\section{Availability of data and materials}

The datasets generated and/or analyzed during the current study are available from the corresponding author on reasonable request.

\section{Consent for publication}

Not applicable.

\section{Ethical statement}

All capture, radio-tag and tracking procedures on Chinese Grouse used in the present study had been given prior approval and were supervised by the Animal Care and Use Committee of the Institute of Zoology, the Chinese Academy of Sciences (Project No. 2008/73).

\section{Funding}

This research was supported by grants from the National Natural Science Foundation of China (NSFC, 31520103903).

Received: 26 October 2017 Accepted: 24 November 2017

Published online: 11 December 2017

\section{References}

Akaike H. A new look at the statistical model identification. IEEE Trans Autom Control. 1974;19:716-23.

Akresh ME, King DI, Brooks RT. Demographic response of a shrubland bird to habitat creation, succession, and disturbance in a dynamic landscape. For Ecol Manag. 2015;336:72-80.

Barg JJ, Aiama DM, Jones J, Robertson RJ. Within-territory habitat use and microhabitat selection by male cerulean warblers (Dendroica cerulea). Auk. 2006;123:795-806

Barg JJ, Jones J, Robertson RJ. Describing breeding territories of migratory passerines: suggestions for sampling, choice of estimator, and delineation of core areas. J Anim Ecol. 2004;74:139-49.

Bergmann HH, Klaus S, Muller F, Scherzinger W, Swenson JE, Wiesner J. Die Haselhühner, Bonasa bonasia und B. sewerzowi Die Neue Brehm-Bücherei. Magdeburg: Westarp Wissenschaften; 1996 (in German).

Beyer HL. Geospatial modelling environment (version 0.7.3.0). 2012. http:// www.spatialecology.com/gme.

Boves TJ, Buehler DA, Sheehan J, Wood PB, Rodewald AD, Larkin JL, Keyser PD, Newell FL, Evans A, George GA. Spatial variation in breeding habitat selection by Cerulean Warblers (Setophaga cerulea) throughout the Appalachian Mountains. Auk. 2013;130:46-59.

Bump G, Darrow R, Edminster F, Crissey W. The ruffed grouse-life history, propagation, management. Aspen Bibliogr. 1947:6703.

Burnham KP, Anderson DR. Model selection and multimodel inference: a practical information-theoretic approach. J Wildl Manag. 2002;67:175-96.

Canfield R. Application of the line interception method in sampling range vegetation. J For. 1941;39:388-94.

Chalfoun AD, Schmidt KA. Adaptive breeding-habitat selection: is it for the birds? Auk. 2012;129:589-99.

Daubenmire R. A canopy-coverage method of vegetational anaysis. Northwest Sci. 1959:50:431.

Dussault C, Ouellet J, Courtois R, Huot J, Breton L, Jolicoeur H. Linking moose habitat selection to limiting factors. Ecography. 2005;28:619-28.

Gullion GW. Forest manipulation for ruffed grouse. In: Wildlife Management Institute, editor. Transactions of the 42nd North American Wildlife Conference. 1977. p. 449-58

Hollander FA, Van DH, San MG, Titeux N. Maladaptive habitat selection of a migratory passerine bird in a human-modified landscape. PLoS ONE. 2011;6:e25703.

Holt CA, Fuller RJ, Dolman PM. Breeding and post-breeding responses of woodland birds to modification of habitat structure by deer. Biol Conserv. 2011;144:2151-62.

Hosmer D, Lemeshow S. Applied logistic regression. 2nd ed. New York: Wiley; 2000

Janzen FJ, Stern HS. Logistic regression for empirical studies of multivariate selection. Evolution. 1998;52:1564-71.

Ji T, Jia CX, Jiang YX, Sun YH. Spring habitat selection of Chinese grouse at Lianhuashan. Chin J Zool. 2005:40:49-53 (in Chinese)

Jones J. Habitat selection studies in avian ecology: a critical review. Auk. 2001;118:557-62.

Jones JA, Siefferman L. Physical habitat quality and interspecific competition interact to influence territory settlement and reproductive success in a cavity nesting bird. Front Ecol Evol. 2014;2:71.

Keating K, Cherry S. Use and interpretation of logistic regression in habitatselection studies. J Wildl Manag. 2004:68:774-89. 
Klaus S, Scherzinger W, Sun YH. Ökologie und verhalten des Chinahaselhuhns Bonasa sewerzowi. Ornithol Beob. 1996;93:343-65 (in German)

Koenig WD, Knops JM. Patterns of annual seed production by northern hemisphere trees: a global perspective. Am Nat. 2000;155:59-69.

Leonard K, Reese K, Connelly J. Distribution, movements and habitats of sage grouse Centrocercus urophasianus on the Upper Snake River Plain of Idaho: changes from the 1950s to the 1990s. Wildl Biol. 2000;6:265-70.

Liu H. Estimating the location of the focal center in red squirrel home ranges, Ecology. 1987;68:1092-101.

Ludwig T, Klaus S. Habitat selection in the post-breeding period by Hazel Grouse Tetrastes bonasia in the Bohemian Forest. J Ornithol. 2016;158:1-12.

Mayor S, Schneider D, Schaefer J, Mahoney S. Habitat selection at multiple scales. Ecoscience. 2009;16:238-47.

Morris D. Toward an ecological synthesis: a case for habitat selection. Oecologia. 2003;136:1-13.

Nystrand M, Griesser M, Eggers S, Ekman J. Habitat-specific demography and source-sink dynamics in a population of Siberian jays. J Anim Ecol. 2010;79:266-74

Rahman ML, Tarrant S, Mccollin D, Ollerton J. Influence of habitat quality, landscape structure and food resources on breeding skylark (Alauda arvensis) territory distribution on restored landfill sites. Landsc Urban Plan. 2012;105:281-7.

Reiley BM, Benson TJ, Bednarz JC. Mechanisms of flood-induced territory abandonment in an obligate ground-foraging bird. Condor. 2013;115:650-8.

Schäublin S, Bollmann K. Winter habitat selection and conservation of Hazel Grouse (Bonasa bonasia) in mountain forests. J Ornithol. 2011;152:179-92.

Sergio F, Pedrini P, Marchesi L. Adaptive selection of foraging and nesting habitat by black kites (Milvus migrans) and its implications for conservation: a multi-scale approach. Biol Conserv. 2003;112:351-62.

Sun YH. Distribution and status of the Chinese grouse Bonasa sewerzowi. Wildl Biol. 2000;6:271-5.

Sun YH. Distribution, reproductive strategy and population biology of the Chinese grouse (Bonasa sewerzowi). Ph.D. Thesis. Beijing: Beijing Normal University; 2004.

Sun YH, Fang Y. Chinese grouse (Bonasa sewerzowi): its natural history, behavior and conservation. Chin Birds. 2010;1:215-20

Sun YH, Fang Y. Notes on the natural history and behaviour of the Chinese grouse Bonasa sewerzowi. Wildl Biol. 1997;3:265-8.
Sun YH, Fang Y, Jia CX, Klaus S, Swenson JE, Scherzinger W. Nest site selection of Chinese grouse Bonasa sewerzowi at Lianhuashan, Gansu, China. Wildl Biol. 2007;13:68-72.

Sun YH, Klaus S, Fang Y, Selsam P, Jia C. Habitat isolation and fragmentation of the Chinese grouse (Bonasa sewerzowi) at Lianhuashan Mountains, Gansu, China. Acta Zool Sin. 2006;52:202-4.

Sun YH, Swenson JE, Fang Y, Klaus S, Scherzinger W. Population ecology of the Chinese grouse, Bonasa sewerzowi, in a fragmented landscape. Biol Conserv. 2003;110:177-84.

Swenson J, Andreev A, Drovetskii S. Factors shaping winter social organization in Hazel Grouse Bonasa bonasia: a comparative study in the eastern and western Palearctic. J Avian Biol. 1995;26:4-12.

Swenson JE. The importance of alder to hazel grouse in Fennoscandian boreal forest: evidence from four levels of scale. Ecography. 1993;16:37-46.

Wallestad R, Schladweiler P. Breeding season movements and habitat selection of male sage grouse. J Wildl Manag. 1974;38:634-7.

Wang J, Yang C, Lu N, Fang Y, Sun YH. Diet of Chinese grouse (Tetrastes sewerzowi) during preincubation. Wilson J Ornithol. 2010;122:177-80.

Wegge P, Olstad T, Gregersen H, Hjeljord O, Sivkov AV. Capercaillie broods in pristine boreal forest in northwestern Russia: the importance of insects and cover in habitat selection. Can J Zool. 2005;83:1547-55.

White G, Garrott R. Analysis of wildlife radio-tracking data. San Diego: Academic Press; 1990.

Yang C, Fang Y, Sun YH. Winter space use and social behaviors of Chinese Grouse at Lianhuashan mountains, Gansu, China. J Ornithol. 2011;152:297-305.

Young L, Zheng GM, Zhang ZW. Winter movements and habitat use by Cabot's Tragopans Tragopan caboti in southeastern China. Ibis. 1991;133:121-6.

Zhang Z, Swaisgood RR, Zhang S, Nordstrom LA, Wang H, Gu X, Hu J, Wei F. Old-growth forest is what giant pandas really need. Biol Lett. 2011. https://doi.org/10.1098/rsbl.2010.1081.

Zhao JM, Fang Y, Lou YQ, Sun YH. Brood habitat selection of Chinese grouse (Tetrastes sewerzowi) at Lianhuashan, Gansu, China. Wilson J Ornithol. 2015;127:310-8.

Zheng G, Wang Q. China red data book of endangered animals: aves. Beijing: Science Press; 1998. p. 51-2.

\section{Submit your next manuscript to BioMed Central and we will help you at every step:}

- We accept pre-submission inquiries

- Our selector tool helps you to find the most relevant journal

- We provide round the clock customer support

- Convenient online submission

- Thorough peer review

- Inclusion in PubMed and all major indexing services

- Maximum visibility for your research

Submit your manuscript at www.biomedcentral com/submit
BioMed Central 